Meeting abstract

\title{
P4P in Australia
}

Stephen Duckett

Address: Queensland Health, Level 18, Queensland Health Building, 147 - 163 Charlotte Street, Brisbane, Australia

Email: Stephen Duckett - Stephen_Duckett@health.qld.gov.au

from 23rd Patient Classifications Systems International (PCSI) Working Conference

Venice, Italy. 7-I0 November 2007

Published: 26 November 2007

BMC Health Services Research 2007, 7(Suppl I):A12 doi:I0.1186/1472-6963-7-SI-AI2

This abstract is available from: http://www.biomedcentral.com/I472-6963/7/SI/AI2

(c) 2007 Duckett; licensee BioMed Central Ltd.

\section{Introduction}

Following a high profile scandal relating to quality and safety of care, the health authority in the Australian state of Queensland is introducing a pay for payment (P4P) component into its new hospital prospective payment system.

\section{Discussion}

P4P will include both pay for reporting to collect additional clinical data and payment for adherence to key clinical process makers. This paper describes the model used to choose conditions amenable to use in a P4P system, together with detail of the indicators used for payment. 